\title{
Synthesis and Characterization of Some New Coumarin Derivatives as Probable Breast Anticancer MCF-7 Drugs
}

\author{
Ahmed Gaber 1,2过, Walaa F. Alsanie ${ }^{2,3}$, Majid Alhomrani ${ }^{2,3}$, Abdulhakeem S. Alamri ${ }^{2,3}{ }^{\mathbb{D}}$, Ibrahim M. El-Deen ${ }^{4}$ \\ and Moamen S. Refat ${ }^{5, *(1)}$ \\ 1 Department of Biology, College of Science, Taif University, P.O. Box 11099, Taif 21944, Saudi Arabia; \\ a.gaber@tu.edu.sa \\ 2 Center of Biomedical Sciences Research (CBSR), Taif University, P.O. Box 11099, Taif 21944, Saudi Arabia; \\ w.alsanie@tu.edu.sa (W.F.A.); m.alhomrani@tu.edu.sa (M.A.); a.alamri@tu.edu.sa (A.S.A.) \\ 3 Department of Clinical Laboratories Sciences, The Faculty of Applied Medical Sciences, Taif University, \\ P.O. Box 11099, Taif 21944, Saudi Arabia \\ 4 Department of Chemistry, Faculty of Science, Port Said University, Port Said 42511, Egypt; \\ Ibrahimm@psu.edu.eg \\ 5 Department of Chemistry, College of Science, Taif University, P.O. Box 11099, Taif 21944, Saudi Arabia \\ * Correspondence: moamen@tu.edu.sa
}

check for updates

Citation: Gaber, A.; Alsanie, W.F.; Alhomrani, M.; Alamri, A.S.; El-Deen, I.M.; Refat, M.S. Synthesis and Characterization of Some New Coumarin Derivatives as Probable Breast Anticancer MCF-7 Drugs. Crystals 2021, 11, 565. https:// doi.org/10.3390/cryst11050565

Academic Editors: Marian Valko and Younes Hanifehpour

Received: 24 March 2021

Accepted: 15 May 2021

Published: 19 May 2021

Publisher's Note: MDPI stays neutral with regard to jurisdictional claims in published maps and institutional affiliations.

Copyright: (c) 2021 by the authors. Licensee MDPI, Basel, Switzerland. This article is an open access article distributed under the terms and conditions of the Creative Commons Attribution (CC BY) license (https:// creativecommons.org/licenses/by/ $4.0 /)$

\begin{abstract}
This study aimed to synthesize quinolinone derivatives and investigate their cytotoxic activity. The compound 1-azacoumarin-3-carboxylic acid (2-oxo-1H-quinoline-3-carboxylic acid) was obtained via the cyclocondensation of 2-hydroxybenzaldehyde with diethyl malonate in base catalyst to give ethyl coumarin-3-carboxylate, followed by the ammonolysis of ester (ethyl coumarin3 -carboxylate) with ammonia in the presence of anhydrous potassium carbonate. Treatment of 2-oxo-1H-quinoline-3-carboxylic acid with acetic anhydride, cinnamaldehyde, cinnamic acid and methyl 5-phenyl-2-cyano-2,4-pentadienoate under different conditions led to the formation of 1 (substituted) aza coumarin-3-carboxylic acids (1-N-(acetyl)-azacoumarin-3-carboxylic acid, 1-N(2-Formyl-1-phenyl) vinyl-azacoumarin-3-carboxylic acids, 1- $N$-[2-(Hydroxy) carbonyl-1-(Phenyl) vinyl]-azacoumarin-3-carboxylic acid and 1-N-(4-Cyano-5-methoxy-5-oxo-1-Phenylpenta-1,3-diene-1y)-azacoumarin-3-carboxylic 284 acid), respectively. The structures of synthesized 1-(substituted) azacoumarin-3-carboxylic acids were confirmed based on spectroscopic methods (IR and NMR), along with elemental analyses. Interestingly compound 6 demonstrated probable impacts as an anti-cancer drug against the MCF-7 cell line. The mechanism of action was assessed using a flow cytometric assay. The outcomes revealed that compound 6 could arrest the cell cycle at G2/M phase and pre-G1 apoptosis.
\end{abstract}

Keywords: anticancer drugs; quinolinone derivatives; MCF-7; cell cycle arrest

\section{Introduction}

Coumarins can be synthesized using a variety of methods, including the Perkin reaction, Knoevenagel condensation, Pechmann condensation, Wittig reaction, Baylis-Hillman reaction, Claisen rearrangement, and Vilsmeier-Haack and Suzuki cross-coupling reactions [1]. Many studies on the medicinal properties of coumarins have been published [2]. Coumarins have antimicrobial effects, including antibacterial [3] and antifungal [4] properties. Several coumarin derivatives have been shown to have antioxidant activity [5]. Some coumarins have been synthesized as acetylcholinesterase (AchE) inhibitors, which may be used to treat Alzheimer's disease [6]. Additionally, coumarins have a variety of biological properties, including anti-inflammatory [7], anti-HIV [8], anticancer [9], antituberculosis [10], anticoagulant [11], antiviral [12], and antihyperglycemic characteristics [13]. Coumarins have been proven to be efficient pharmacophores; therefore, demand for their synthesis is increasing. Many methods have been employed for their synthesis, each of which uses different starting materials and reaction conditions. 
The green synthesis of coumarin derivatives in deep eutectic solvent (DES) by Knoevenagel condensation was reported by Keshavarzipour and Tavakol [14]. At $100{ }^{\circ} \mathrm{C}$, DES was made by mixing choline chloride $(\mathrm{ChCl})$ and zinc chloride. Easy or substituted salicylaldehydes (4hydroxy, 5bromo) and methylene compounds (dimethyl malonate, ethyl cyanoacetate, ethyl 3-oxo-3-phenylpropanoate) were used to make coumarin derivatives. The synthesis of coumarins by the Knoevenagel condensation of salicylaldehyde and diethyl malonate in EtOH was reported by Sulji and Pietruszka [15]. Piperidine and acetic acid were used as catalysts. In the method of continuous flow hydrogenation, chromanones were obtained from the synthesized coumarins.

Silveira Pinto and Souza used Knoevenagel condensation to synthesize various coumarins from active methylene compounds (diethylmalonate, Meldrum's acid, and ethylcyanoacetate) and salicylaldehydes [16]. Piperidine and glacial $\mathrm{AcOH}$ were added to the reaction, which was carried out in pure $\mathrm{EtOH}$ or $\mathrm{H}_{2} \mathrm{O}$. A model reaction of salicylaldehyde and diethyl malonate was carried out using a heating and ultrasonic process. In the case of ultrasound irradiation, the yield is higher and the reaction time is shorter, as compared to the reflux treatment ( $40 \mathrm{~min}$ compared with $7 \mathrm{~h}$ ). Various coumarins were obtained using ultrasound irradiation at a frequency of $20 \mathrm{kHz}$ with a power output of $90 \%$ and no pulsing.

From the published research, it has been reported that quinoline derivatives may have an anti-cancer effect through many diverse mechanisms, for example, cell cycle arrest in the G2 phase [17,18], inhibition of the formation of topoisomerase enzyme [18], inhibition of polymerization, and the formation of tubulin during the cell cycle [19]. The most well-known mechanism is inhibition of the tyrosine kinase enzyme [20-23], especially the enzyme known as the vascular epithelial growth factor receptor tyrosine kinase [24-27]. Kemnitzer et al. [28] found a new series of apoptosis inducers (Figure 1), the 1-benzoyl3 -cyanopyrrolo[1,2- $a]$ quinolines (I), among which the compound 1-(4-(1-h-imidazol-1yl)benzoyl)-3-cyanopyrrolo[1,2-a]quinoline (II) displayed high cytotoxic activity in T47D human breast cancer, HCT-116 human colon cancer cells, and SNU398 hepatocellular carcinoma cells.

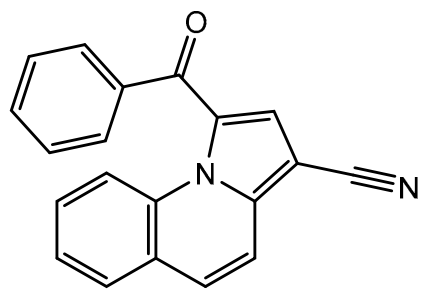

(A) I

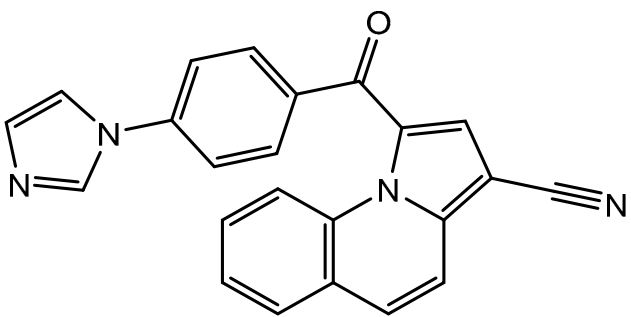

(B) II

Figure 1. (A)Structures of 1-benzoyl-3-cyanopyrrolo[1,2-a] quinolines (I), and (B)1-(4-(1-h-imidazol1-yl)benzoyl)-3-cyanopyrrolo[1,2-a]quinoline (II).

Coumarins are molecules that belong to a very special family [29]. The conjugated double-ring system gained the importance of the molecule in various fields of research [29]. Coumarin is used in contemporary industry, in many products; for example, cosmetics, perfumes, and as a food additive, in addition to its entry into the pharmaceutical industry, where it is used in the production of many synthetic pharmaceutical materials [30]. This last application is the main point of our research. There were many reports published in 2020 confirming the importance of coumarin use as an anti-cancer agent [31-35]. Additionally, the design of sulfamide 3-benzylcoumarin hybrids bearing an oxadiazole ring at position 7 has enabled the preparation of new multitarget mitogen-activated protein kinase inhibitors and nitric oxide donors, both of which can be used due to their antiproliferative properties [36]. 
Encouraged by these observations and in continuation the work on the studies of coumarin as an anti-cancer drug, we report the synthesis of a new class of azacoumarin-3carboxylic acid derivatives to determine the appropriate replacement/addition of different moieties leading to better inhibitors for cancer cells. These designed molecules have been synthesized and characterized by known methods with slight modifications wherever required. The presence of 1-N-(2-Formyl-1-phenyl) vinyl-azacoumarin-3-carboxylic acids (5), $1-\mathrm{N}$-[2-(Hydroxy) caybonyl-1-(Phenyl) vinyl]-azacoumarin-3-carboxylic acid (6), and 1-N(4-Cyano-5-methoxy-5-oxo-1-Phenylpenta-1,3-diene-1-y)-azacoumarin-3-cayboxylic acid (9) compounds formed from the refluxed mixture of 2-oxo- $1 \mathrm{H}$-quinoline-3-carboxylic acid (3) (0.01 mole), and $\alpha, \beta-5$-unsaturated carbonyl compounds (namely, cinnamaldehyde, cinnamic, acid and methyl 5-phenyl-2-cyano-2,4-pentadine oats (0.01 mole)) in $50 \mathrm{~mL}$ dimethylformamide for $4 \mathrm{~h}$. The experimental data led us to design and synthesize the novel derivatives as probable MCF-7 anti-cancer moieties.

\section{Results and Discussion}

\subsection{Chemistry}

The synthetic pathway which leads to $\mathrm{N}$-substituted azacoumarin-3-carboxylic acids (3-6 and 9) is presented in Schemes 1-3. The reaction sequence steps include: the cyclocondensation of 2-hydroxybenzaldehyde (1) with diethyl malonate in the presence of piperidine as a base catalyst to afford ethyl coumarin-3-carboxylate (2); and the ammonolysis of ester coumarin (2) with ammonia solution, in ethanol, in the presence of anhydrous potassium carbonate under reflux, which produced the corresponding 2-oxo-1h-quinoline3-carboxylic acid (3) (Scheme 1).

The structure of the achieved compounds was clarified by spectral data (Figures S1-S3 Supplementary Materials). The IR spectrum critical stretching bands fitting to $\mathrm{OH}$, $\mathrm{NH}, \mathrm{C}=\mathrm{O}$ of acid and amide, $\mathrm{C}=\mathrm{C}$, and $\mathrm{C}-\mathrm{O}$ groups were detected at the anticipated regions (Figure S1). The complete aromatic and pyridinone proton peaks in the H-NMR spectrum of compound 3 were in the estimated areas (Figure S2). The ${ }^{13} \mathrm{C}-\mathrm{NMR}$ spectrum of compounds showed three carbon signals at $\delta=163-00,160.80$ and $154.51 \mathrm{ppm}$, referring to the two carbonyl $(\mathrm{C}=\mathrm{O})$ and $\mathrm{C}-\mathrm{N}$ groups (Figure $\mathrm{S} 3$ ). The signals present at $\delta=148.28$ ppm and signals within the region at $134-116.60 \mathrm{ppm}$ are assigned to the $\mathrm{C}-4$ carbon signal of 1-azacoumarin and aromatic carbons as well as $\mathrm{C}-3$ of pyridinone rings.

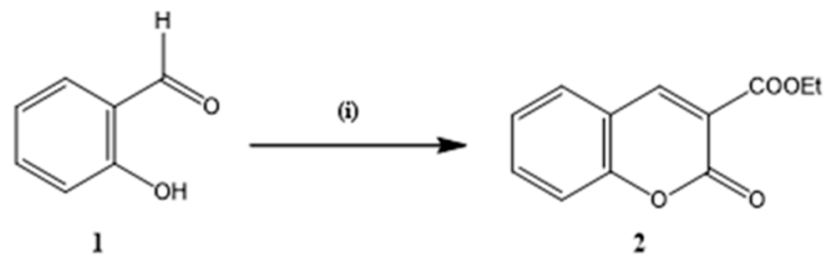<smiles>O=C(O)c1cc2ccccc2[nH]c1=O</smiles>

Scheme 1. Synthesis of 1-azacoumarin-3-carboxylic acid (3). Reagents and reaction conditions: (i) diethyl malonate, piperidine/EtOH; (ii) ammonia solution (33\%), $\mathrm{K}_{2} \mathrm{CO}_{3} / \mathrm{EtOH}$.

Additionally, the structure of compound 3 was verified chemically through its conversion into 1- $\mathrm{N}$-(substituted)- azacoumarin-3- carboxylic acid (4) by boiling in acetic 
anhydride under reflux 1-N-(2-formyl-1-phenyl) vinylazacoumarin-3-carboxylic acids (5) and 1-N-[2-(hydroxy carbonyl)-1-(phenyl) vinylazacoumarine-3-carboxylic acid (6). Compounds 5 and 6 were synthesized by a condensation reaction of compound 3 with cinnamaldehyde and cinnamic acid in dimethyl formamide in the presence of triethylamine, followed by dehydrogenation under reflux (Scheme 2).

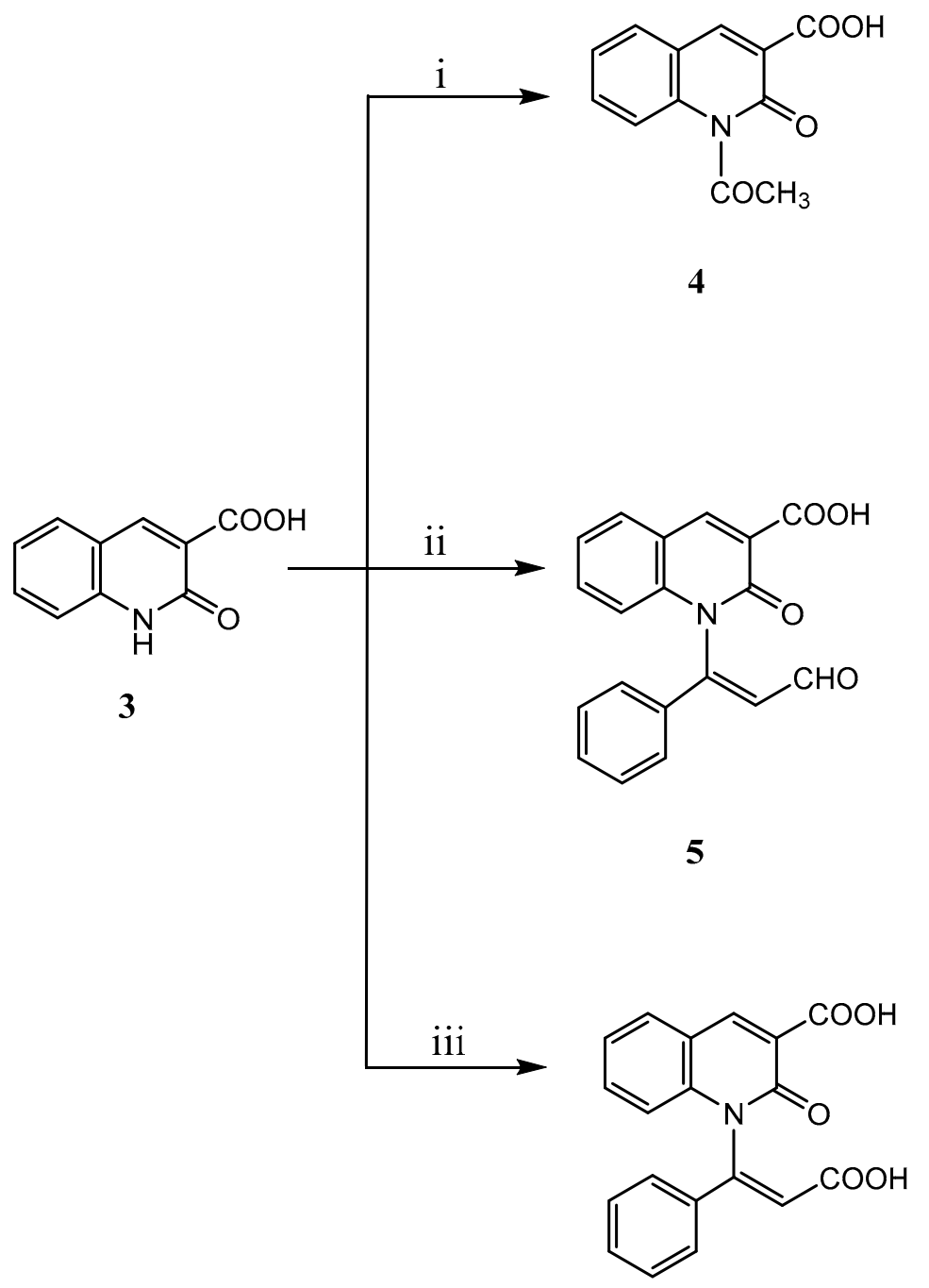

6<smiles>CCN1CCC(C)CC1</smiles>

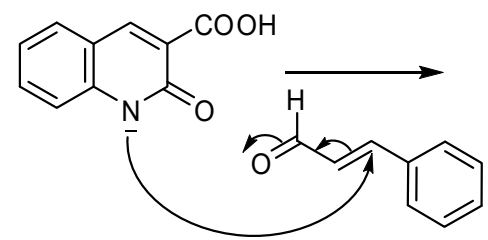<smiles>CC(C)(C=CC=O)c1ccccc1</smiles>

Scheme 2. Synthesis of 1-N-(substituted)-azacoumarin-3-Carboxylic acids (4-6). Reagents and reaction conditions: (i) acetic anhydride; (ii) cinnamaldehyde, $\mathrm{Et}_{3} \mathrm{~N} / \mathrm{DMF}$; (iii) cinnamic acids, $\mathrm{Et}_{3} \mathrm{~N} / \mathrm{DMF}$.

The data of ${ }^{1} \mathrm{H}-\mathrm{NMR}$ spectrum of compound 4 displayed a new singlet signal at $\delta=2.38$, allocated to the protons of methyl function for the acetyl $\left(\mathrm{COCH}_{3}\right)$ group (Figure S4). The proton signals of 1-azacoumarin and hydroxyl $(\mathrm{OH})$ groups were detected within the anticipated chemical shifts regions with the expected integral values (Figure S4). The 
presence of new two carbon signals at $\delta=190.59$ and $21.27 \mathrm{ppm}$ in the ${ }^{13} \mathrm{C}-\mathrm{NMR}$ spectrum of compound indicated the presence of an acetyl $\left(\mathrm{CH}_{3} \mathrm{CO}\right)$ group (Figure S5). These signals further supported the formation of compound 4. Additionally, the ${ }^{13} \mathrm{C}-\mathrm{NMR}$ spectrum of compound 4 exhibited the same carbon signals as in compound 3, which gave a total of 12 carbon signals (Figure S5).<smiles>CC(=O)OC(C)=CC=Cc1ccccc1</smiles><smiles>COC(=O)CC#N</smiles><smiles>COC(=O)C(C#N)SCCCCCCC(=O)C=Cc1ccccc1</smiles><smiles>COC(=O)/C(C#N)=C\C=C\c1ccccc1</smiles>

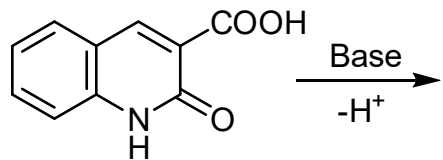<smiles>CCCCCCn1c(=O)c(C(=O)O)cc2ccccc21</smiles><smiles>COC(=O)/C(C#N)=C/C=C/c1ccccc1</smiles><smiles>COC(=O)/C(C#N)=C\C=C(/c1ccccc1)n1c(=O)c(C(=O)O)cc2ccccc21</smiles><smiles>COC(=O)C1=CC=CC(=CC=CC(=O)n2c(=O)c(C(=O)O)cc3ccccc32)c2ccccc21</smiles>

Scheme 3. Synthesis of 1-N-(4-cyano-5-methoxy-5-oxo-1-phenylpenta-b3-diene-1-y1)- azacoumarin-3-carboxylic acid (9). Reagents and reaction conditions: (i) methyl cyanoacetate, piperidine/ $\mathrm{MeOH}$; (ii) 1- $\mathrm{N}$ - azacoumarin-3-carboxylic acid, $\mathrm{Et}_{3} \mathrm{~N} / \mathrm{DMF}$.

The ${ }^{1} \mathrm{H}-\mathrm{NMR}$ spectra of compounds 5 and $\mathbf{6}$ exhibited sharp singlet signals at $\delta=9.83$ and $12.46 \mathrm{ppm}$ due to the protons of formyl $(\mathrm{CHO})$ and carboxylic $(\mathrm{COOH})$ groups (Figures S6 and S8). The H-4 protons of azacoumarin demonstrated a singlet signal at $\delta=8.89 \mathrm{ppm}$ in compounds $\mathbf{5}$ and $\mathbf{6}$. Protons of the aromatic ring and olefinic were observed as multiple signals in the region at $\delta=6.54-8.10 \mathrm{ppm}$. Additionally, the ${ }^{13} \mathrm{C}$ - 
NMR spectra of compounds 5 and $\mathbf{6}$ displayed two new carbon signals at $\delta=194.95$ and $168.09 \mathrm{ppm}$, referring to carbons of formyl and carboxylic groups (Figures S7 and S9). The remaining carbon of carbonyl signals of acid and amide appeared in the ${ }^{13} \mathrm{C}-\mathrm{NMR}$ spectra of compounds 5 and 6 in the regions at $\delta=162-99,163.00$, and 160.80, 160.82 ppm.

The methyl 5-phenyl-2-cyano-2,4-pentadieneoate (8) compound was synthesized by the condensation of cinnamaldehyde (7) with methyl cyanoacetate in the presence of a piperidine in situ methanol solvent. Finally, treatment of compound 8 with 1$\mathrm{N}$-azacoumarin-3-carboxylic acid (3) in dimethyl formamide, with the existence of triethylamine under reflux, produced the corresponding 1-N-[4-cyano-5-methoxy-5-oxo-1phenylpenta 1,3-diene-1-yl)-azacoumarin-3-carboxylic acid (9) (Scheme 3).

The ${ }^{1} \mathrm{H}-\mathrm{NMR}$ spectrum of compound 9 displayed two characteristic singlets at $\delta=3.75$ and $8.89 \mathrm{ppm}$, referring to the protons of methoxy $\left(\mathrm{OCH}_{3}\right)$ group and $\mathrm{H}-4$ of $\mathrm{N}$-aza coumarin ring (Figure S10). Protons of aromatic rings, olefin, and hydroxy functions of the carboxylic group were observed in the ${ }^{1} \mathrm{H}-\mathrm{NMR}$ spectrum of this compound in the region at $\delta=7.24-8.44 \mathrm{ppm}$ (Figure S10). The ${ }^{13} \mathrm{C}-\mathrm{NMR}$ spectrum of compound 9 showed three new carbon signals at $\delta=162.80,103.39$, and $53.32 \mathrm{ppm}$ due to the carbons of carbonyl (ester), cyano, and methoxy $\left(\mathrm{OCH}_{3}\right)$ groups (Figure $\left.\mathrm{S11}\right)$. Additionally, the carbon signals of two carbonyl groups in the 1- $\mathrm{N}$-azacoumarin-3-carboxylic acid ring appeared at $\delta=163.00$ and $160.82 \mathrm{ppm}$. In addition, characteristic carbon signals due to the aromatic and olefinic groups resonated in the region at $\delta=156.55-118.94 \mathrm{ppm}$ (Figure S11).

\subsection{Anti-Cancer Evaluation}

2.2.1. In Vitro Cytotoxic Activity of the Synthesized Compounds Against MCF-7 Cell Line

The synthesized compounds 3-6 and $\mathbf{9}$ were assessed for their anti-cancer activity against MCF-7 using 3-[4,5-dimethylthiazol-2-yl]-2,5-diphenyltetrazolium bromide (MTT) assay to assess cell viability. Doxorubicin (Dox) was utilized as a reference drug control. The data are reported as compound concentrations causing a net $50 \%$ loss of initial cells $\left(\mathrm{IC}_{50}\right)$ (Table 1$)$. The acquired data of the tested quinolinone derivatives 3-6 and $\mathbf{9}$ showed that compound 6 was the most effective compound against the MCF-7 cell line, with IC 50 values of $2.56 \pm 0.13$, in contrast to Dox $\mathrm{IC}_{50}=2.82 \pm 0.07 \mu \mathrm{M}$. Moreover, compounds 5 and 6 revealed moderate cytotoxic activity with $\mathrm{IC}_{50}$ values of $10.13 \pm 0.83$ and $14.06 \pm 0.63 \mu \mathrm{M}$, respectively (Table 1 ).

Table 1. In vitro anti-cancer activity of quinolinone derivatives 3-6 and 9.

\begin{tabular}{cc}
\hline Compound & IC $_{\mathbf{5 0}}$ Values $(\boldsymbol{\mu M}) /$ MCF-7 \\
\hline $\mathbf{3}$ & $>50$ \\
$\mathbf{4}$ & $>50$ \\
$\mathbf{5}$ & $10.13 \pm 0.83^{\mathrm{b}}$ \\
$\mathbf{6}$ & $2.56 \pm 0.13^{\mathrm{a}}$ \\
$\mathbf{9}$ & $14.06 \pm 0.63^{\mathrm{b}}$ \\
Dox & $2.82 \pm 0.07^{\mathrm{a}}$ \\
\hline
\end{tabular}

$\overline{\text { Each value is the mean of three experiments } \pm \text { SEM. Different superscript letters designate significant differences }}$ $(p<0.05)$ using Duncan's multiple range test.

\subsubsection{Cell Cycle Analysis}

To examine the mechanism underlying the cytotoxic activity of the most active compound (6), the cell cycle distribution profile of MCF-7 cells was measured. MCF-7 cells were incubated with compound 6 at a concentration of $2.56 \mu \mathrm{M}$ for $48 \mathrm{~h}$. As a result, the percentage of MCF-7 cells increased in the G2/M phase by $34.62 \%$ compared with control cells $(12.04 \%)$ (Figure 2). This result suggested that compound 6 causes perturbations in cell cycle progression in the G2/M phase, leading to an inhibition of cell survival. Cell cycle and apoptosis play significant functions in the regulatory mechanisms of cell development and growth. The effect of many substances which are used as anti-cancer agents was found to be through arresting of the cell cycle during the phases G0/G1, S, and G2/M, which 
stimulated and induced apoptosis [37-39]. Thus, we conclude that the effect of compound 6 on cancer cell line was through the disturbances of compound 6 in cell cycle, progression especially in the G2/M phase, suggesting an antimitotic effect.

A

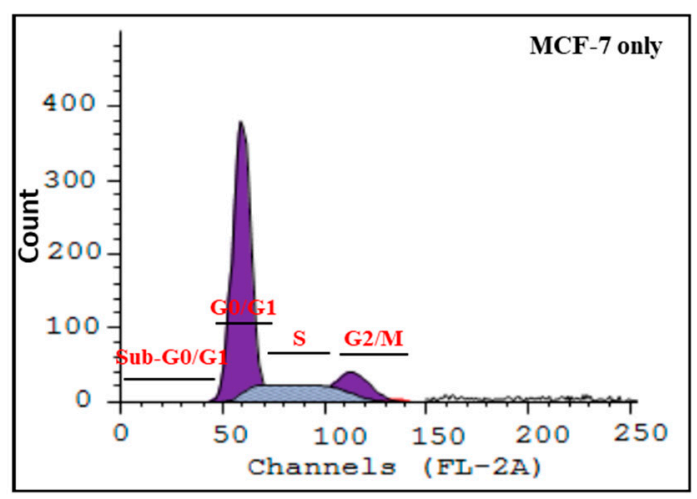

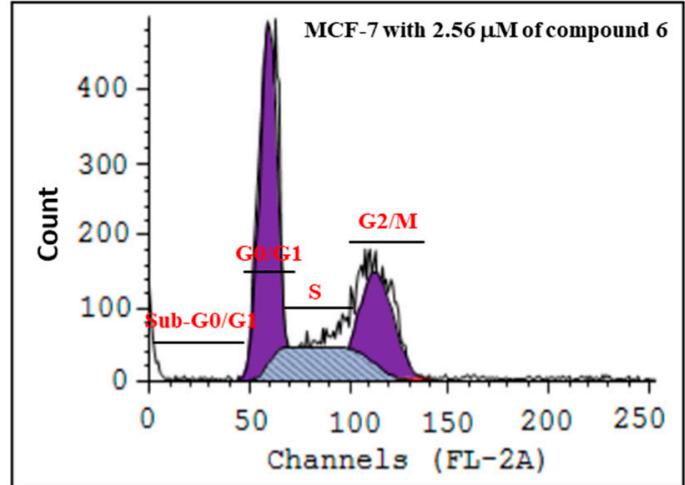

$\square$ Compound 6/MCF-7 $\square$ MCF-7 only

B

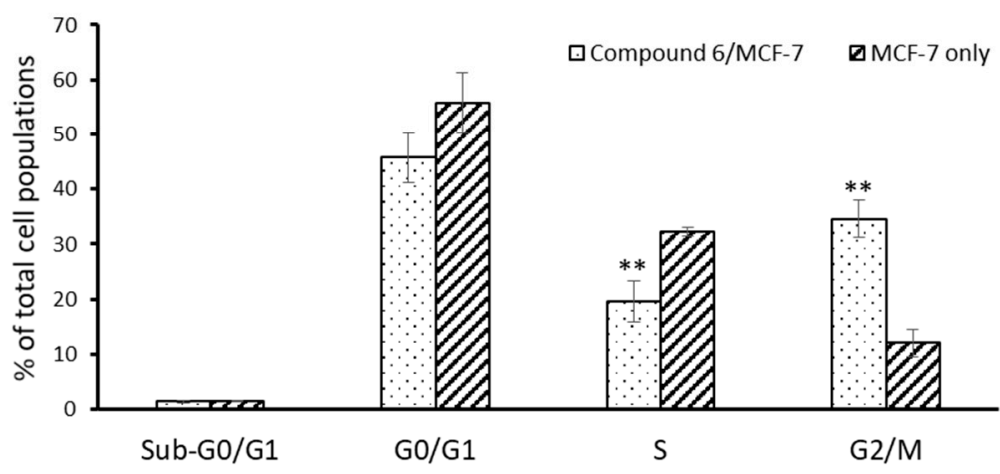

Figure 2. The effect of compound 6 at the concentration of $2.56 \mu \mathrm{M}$ on the MCF-7 cell cycle progression. (A) Representative flow cytometry data of the cell cycle change. (B) Percentage of the total cell populations at each cell cycle phase in each cell. ** $p<0.01$ according to Tukey's test.

\subsubsection{Apoptosis Analysis}

The apoptosis ratio was determined in MCF-7 cells after incubation with compound 6 for $48 \mathrm{~h}$. The results exhibited that compound 6 could enhance the early apoptosis stage by $3.90 \%$ compared with the untreated cells (Figure 3). Moreover, compound 6 could increase the late apoptosis stage by $6.61 \%$ in comparison with the control group (Figure 3). These data indicate the involvement of compound 6 in the apoptosis process of MCF-7 cells. Thus, the flow cytometry investigation of MCF-7 cells indicated that the cancer cell tended to change from viable to apoptotic after the treatment with compound 6 . 

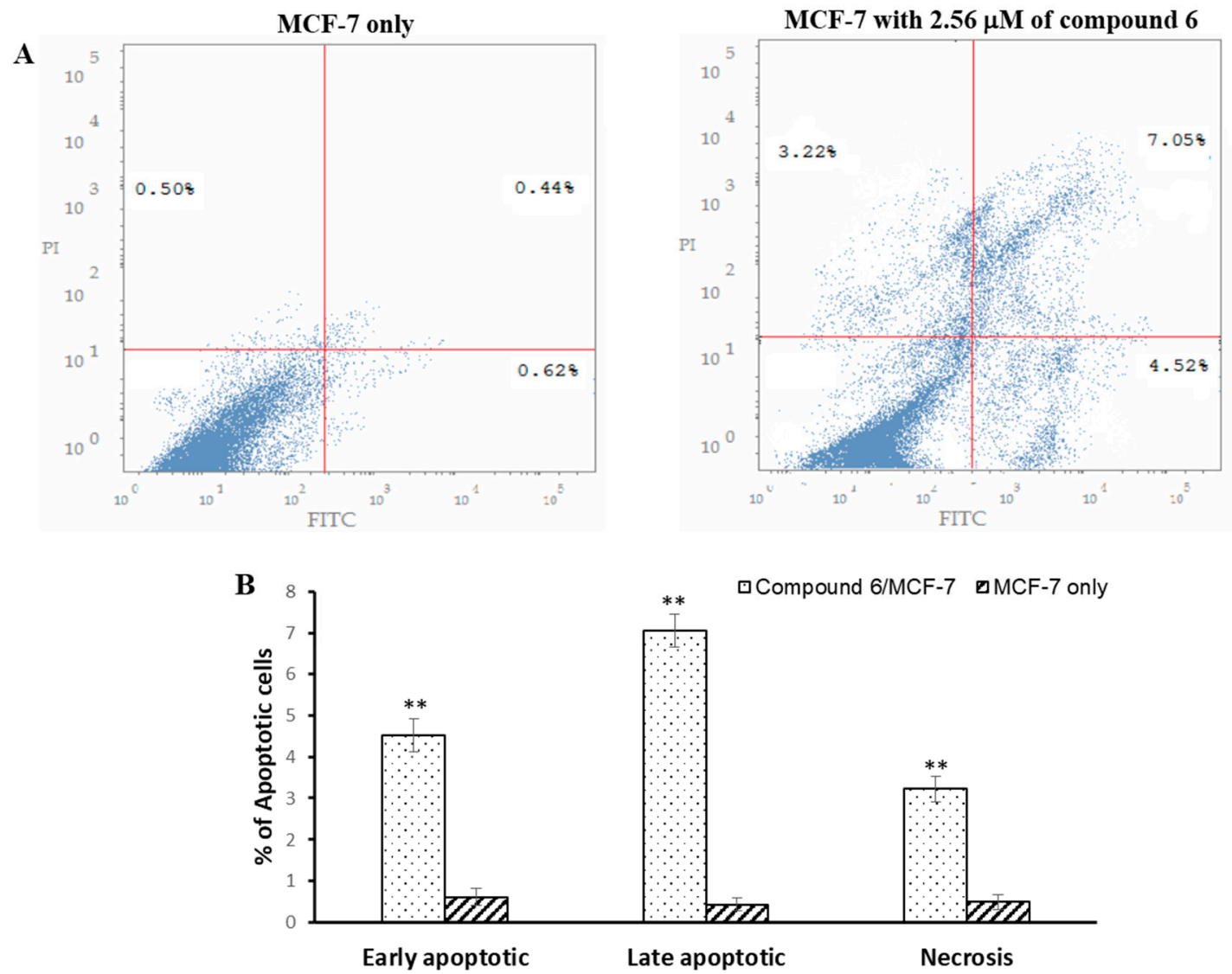

๑Compound 6/MCF-7 $\square$ MCF-7 only

Figure 3. The apoptotic and necrotic cells obtained from MCF-7 cells alone or with compound 6 at a concentration of $2.56 \mu \mathrm{M}$. (A) The flow cytometry results. (B) the percentage of the apoptotic cells. ${ }^{* *} p<0.01$ according to Tukey's test.

\section{Materials and Methods}

Shimadzu 470 Spectrometer apparatus with $\mathrm{KBr}$ pellets verified melting point apparatus (NP-D) and infrared spectra. The ${ }^{1} \mathrm{H}-\mathrm{NMR}$ and ${ }^{13} \mathrm{C}-\mathrm{NMR}$ spectra were obtained using a Bruker $400 \mathrm{NMR} \mathrm{MH}_{2}$ spectrometer in DMSO- $\mathrm{d}_{6}$ and solution using TMS as an internal reference. Chemical shifts are given to $\delta$-scale (ppm). The elemental analysis was performed on a Perkin-Elmer 2400 Series II CHN elemental analyzer. Chemicals used in syntheses were obtained from Aldrich, Merck, and Fluka chemical companies.

\subsection{Synthesis}

The reagent grade chemicals were obtained from commercial sources and purified by either distillation or recrystallization before use. The purity of synthesized compounds was checked by thin layer chromatography (TLC) on silica gel plate using benzene:ethyl acetate.

\subsubsection{Ethyl Coumarin-3-carboxylate (2)}

Ethyl coumain-3-carboxylate (2) was obtained as a starting material via the condensation of 2-hydroxy-benzaldehyde with diethyl malonate in a base catalyst according to previous studies [26], and was authenticated using NMR and IR spectroscopy.

\subsubsection{2-oxo-1H-Quinoline-3-carboxylic Acid (3)}

The ester (compound 2) (0.01 mole) was dissolved in ethanol $(100 \mathrm{~mL})$, anhydrous potassium carbonate $(0.03$ mole) was included, and this mixture was allowed to reflux for $30 \mathrm{~min}$. The ammonia solution $(20 \mathrm{~mL}, 36 \%)$ was added to the reaction mixture and then heated under pressure for $3 \mathrm{~h}$. Next, the mixture was cooled by pouring it into ice water and neutralizing it with dilute hydrochloric acid $(2 \%)$. The resultant solid was filtered off, washed with water, dried, and recrystallized from dimethylformamide to give a colorless 
crystal, yield $63 \%$, m.p. $285^{\circ} \mathrm{C}$ IR $(\mathrm{KBr}) v\left(\mathrm{~cm}^{-1}\right)=3481(\mathrm{br}-\mathrm{OH}), 3368(\mathrm{NH}), 1716,1685$ $(\mathrm{C}=\mathrm{O}), 1605,1563$ (C=C), 1161, 1009 (C-O) $\mathrm{cm}^{-1} ;{ }^{1} \mathrm{H}-\mathrm{NMR}$ (DMSO-d6) 8: 7.42-7.98 (m, 5 $\mathrm{H}, \mathrm{Ar}-\mathrm{H}$ and NH), 8.09 (br.s, $1 \mathrm{H}, \mathrm{OH}), 8.87$ (s, 1H, H-4 of azacoumarin ring); ${ }^{13} \mathrm{C}-\mathrm{NMR}$ $\left(\mathrm{DMSO}_{\mathrm{d}}\right.$ ) $\delta: 163.00$ (C-11), 160.80 (C-2), $154.51(\mathrm{C}-9), 148.26$ (C-4), 134.58 (C-5), 130.74 (C10), 125.56 (C-6), 119.78 (C-7), 118.93(C-8), 116.60 (C-3) ppm. Anal. Calcd. for C10H7NO3 (189): C, 63.49; H, 3.70; N, 7.41. Found: C, 63.18; H, 3.49; N, 7.21.

\subsubsection{1-N-(acetyl)-Azacoumarin-3-carboxylic Acid (4)}

A solution of compound 3 at 0.01 mol was heated in a solution of acetic anhydride $(25 \mathrm{~mL})$ under reflux for $4 \mathrm{~h}$. After that, it was allowed to cool by pouring it into ice water while stirring. The reaction mixture was left for $24 \mathrm{~h}$, and then the precipitate formed was filtered and washed well with water and left to dry. Finally, the product was recrystallized from ethanol to produce 4 (Figure 4) colorless crystals; the yield was $58 \%$, m.p. $170{ }^{\circ} \mathrm{C}$. IR $(\mathrm{KBr}) v\left(\mathrm{~cm}^{-1}\right)=3428-3015(\mathrm{br}-\mathrm{OH}), 1720,1695(\mathrm{C}=\mathrm{O}), 1608,1583$ (C=C), 1112, 1017

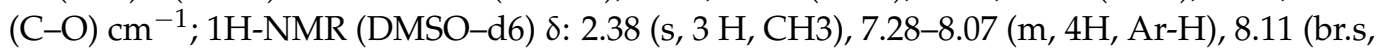
$1 \mathrm{H}, \mathrm{OH}), 8.69$ (s, 1H, H-4 of azacoumarin ring) ppm; ${ }^{13} \mathrm{C}-\mathrm{NMR}$ (DMSO-d6) $\delta: 190.59$ (C-12), 169.79 (C-11), 157.67 (C-2), 150.42 (C-9), 136.21 (C-4), 133.12 (C-5), 131.44 (C-10), 129.2 (C-6), 127.13 (C-7), 126.20 (C-8), 124.12(C-3), 21.27 (C-13) ppm. Anal. Calcd. for C12H9NO4 (231): C, 62.34; H, 3.90; N, 6.06. Found: C, 62.11; H, 3.66; N, 5.88.

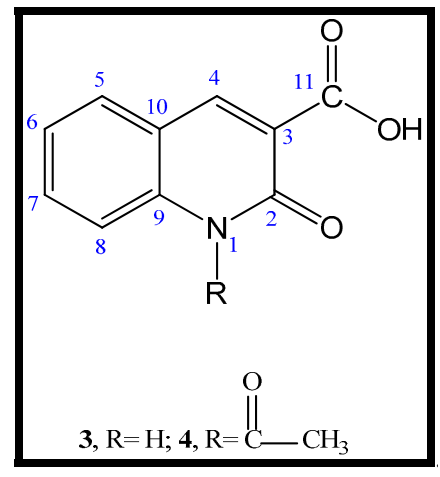

Figure 4. The structure of 1-N-(substituted)-azacoumarin-3- carboxylic acids (compounds 3 and 4).

3.1.4. General Procedure for the Synthesis of 1-N-(substituted)-Azacoumarin-3-carboxylic Acids (5, 6, and 9)

A mixture of compound 3 (0.01 mole) and $\alpha, \beta-5$-unsaturated carbonyl compounds (namely, cinnamaldehyde, cinnamic, acid and methyl 5-phenyl-2-cyano-2,4-pentadine oats ( 0.01 mole) in $50 \mathrm{~mL}$ dimethylformamide was refluxed for $4 \mathrm{~h}$. After cooling, the resultant mixture was poured into water and neutralized with dilute hydrochloric acid ( $2 \%)$. Then, the resulting product was collected after filtration, washed, and dried. Finally, the final formed products were recrystallized from a methanol solvent to give compounds 5,6 and 9 (Figure 5).

\subsubsection{1-N-(2-Formyl-1-phenyl) Vinyl-azacoumarin-3-carboxylic Acids (5)}

Compound 5 was produced as pale-yellow crystals with a yield of $63 \%$, m.p. $187{ }^{\circ} \mathrm{C}$. IR $(\mathrm{KBr}) v\left(\mathrm{~cm}^{-1}\right)=3430$ (br.OH), 1725, 1689 (C=O), 1607, $1583(\mathrm{C}=\mathrm{C}), 1181,1093(\mathrm{C}-\mathrm{O})$ $\mathrm{cm}^{-1} ;{ }^{1} \mathrm{H}-\mathrm{NMR}\left(\mathrm{DMSO}-\mathrm{d}_{6}\right) \delta: 6.81-8.00(\mathrm{~m}, 12 \mathrm{H}, \mathrm{Ar}-\mathrm{H}$ olefinic-H and $\mathrm{OH}), 8.89(\mathrm{~s}, 1 \mathrm{H}$, $\mathrm{H}-4$ of azacoumarin ring), 9.75 (s, 1H, CHO) ppm; ${ }^{13} \mathrm{C}-\mathrm{NMR}\left(\mathrm{DMSO}-\mathrm{d}_{6}\right) \delta: 194.95(\mathrm{C}-20)$, 162.99 (C-11), 160.80 (C-2), 154.51(C-9), 148.28 (C-4), 144.41(C-12), 134.62 (C-16), 134.57 (C-5), 131.70 (C-10), 130.73 (C-13) 129.56, 129.37 (C-15, 17),129.22, 128.64 (C-14,18), 125.56 (C-6), 119.78 (C-7), 119.68 (C-19), 118.93 (C-8), 116.60 (C-3) ppm. Anal. Calcd. $\mathrm{C}_{19} \mathrm{H}_{13} \mathrm{NO}_{4}$ (319): C, 71.47; H, 4.10; N, 4.39. Found: C, 71.26; H, 3.83, N, 4.08. 


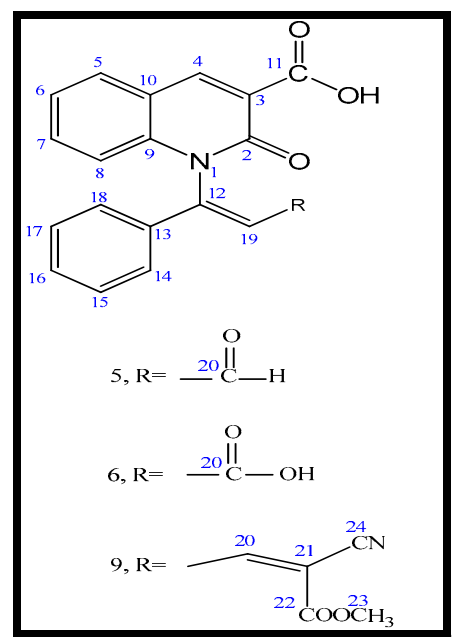

Figure 5. The structure of the derivatives 5, 6, and 9 .

3.1.6. 1-N-[2-(Hydroxy) Caybonyl-1-(phenyl) Vinyl]-azacoumarin-3-carboxylic Acid (6)

Compound 5 was produced as colorless crystals, with a yield of $73 \%$, m.p. $233{ }^{\circ} \mathrm{C}$. IR $(\mathrm{KBr}) v\left(\mathrm{~cm}^{-1}\right)$ : 3451-2985 (br. OH), 1717-1688 (C=O), 1605, $1563(\mathrm{C}=\mathrm{C}), 1178,1089,1021$ (C-O) $\mathrm{cm}^{-1} ;{ }^{1} \mathrm{H}-\mathrm{NMR}$ (DMSO-d 6 ) $\delta: 6.54$ (d, 1H, olefinic), 7.33-8.10 (m, 10 H, Ar-H and $\mathrm{OH}), 8.89$ (s, 1H, H-4 of azacoumarin ring), 12.56 (br.s.,1H, OH) ppm; ${ }^{13} \mathrm{C}-\mathrm{NMR}$ (DMSO$\left.\mathrm{d}_{6}\right) \delta: 168.69$ (C-20), 163.00 (C-11), 160.82 (C-2), 154.52 (C-9), 148.09 (C-4), 144.39 (C-12), 134-70 (C-16), 134.59 (C-5), 130-75 (C-10), 130.71 (C-13), 129.38 (C-15,17), 128.69 (C-14,18), 125.57 (C-6), 119.76 (C-7), 119.73 (C-19), 118.94 (C-8), 116.61 (C-3) ppm. Anal. Calcd. for $\mathrm{C}_{19} \mathrm{H}_{13} \mathrm{NO}_{5}$ (335): C, 68.06; H, 3.91; N, 4.18. Found: C, 67.89; H, 3.58; N, 4.02.

3.1.7. 1-N-(4-Cyano-5-methoxy-5-oxo-1-phenylpenta-1,3-diene-1-y)-azacoumarin-3cayboxylic Acid (9)

Compound 5 was produced as pale yellow crystals, with a yield of $62 \%$, m.p. $198{ }^{\circ} \mathrm{C}$. IR $(\mathrm{KBr}) v\left(\mathrm{~cm}^{-1}\right)=3483-3105$ (br.OH), $2225(\mathrm{CN}), 1735-1689(\mathrm{C}=\mathrm{O}), 1606,1583(\mathrm{C}=\mathrm{C}), 1183$, $1083(\mathrm{C}-\mathrm{O}) \mathrm{cm}^{-1},{ }^{1} \mathrm{H}-\mathrm{NMR}\left(\mathrm{DMSO}_{-} \mathrm{d}_{6}\right) \delta: 3.75$ (s, 3H, $\left.\mathrm{OCH}_{3}\right), 7.24-8.44(\mathrm{~m}, 12 \mathrm{H}, \mathrm{Ar}-\mathrm{H}$, olefinic- $\mathrm{H}$ and $\mathrm{OH}), 8.89$ (s, $1 \mathrm{H}, \mathrm{H}-4$ of azacoumarin ring) ppm; ${ }^{13} \mathrm{C}-\mathrm{NMR}\left(\mathrm{DMSO}-\mathrm{d}_{6}\right) \delta$ : 163.00 (C-11), 162.80 (C-22), 160.82 (C-2), 156.55 (C-12), 154.51 (C-9), 150.70 (C-13), 148.30 (C-4) 135.08 (C-15), 134.58 (C-5), 131.76 (C-16), 130.75 (C-10), 129.72 (C-15, 17), 129.19 (C-14, 18), 128.38 (C-19), 125.56 (C-6), 123.08 (C-21), $119.76(\mathrm{C}-7), 118.94$ (C-8), 103.39 (C-25), 53.32 (C-24) ppm. Anal. Calcd. for $\mathrm{C}_{23} \mathrm{H}_{16} \mathrm{~N}_{2} \mathrm{O}_{5}$ (400): C, 69.00; H, 4.00; N, 7.00. Found: C, 68.83; $\mathrm{H}, 3.73 ; \mathrm{N}, 6.86$.

\subsection{Anti-Cancer Assay}

\subsubsection{In Vitro Anti-Cancer Activity Against Breast Cancer Cell Line (MCF-7)}

To investigate the effect of the synthesized compounds 3-6 and $\mathbf{9}$ as anti-cancer drugs, a cytotoxicity test was performed using the MTT technique. The cells were distributed in a 96-well plate with approximately $10^{4}$ cells/well and then left for $24 \mathrm{~h}$ before adding the synthesized compounds to allow the cell to attach to the plate. After $24 \mathrm{~h}$, different concentrations of the synthesized compounds were added to each cell monolayer. Each concentration had six wells. The 96 -well plates were incubated at $37^{\circ} \mathrm{C}$ in the presence of $5 \% \mathrm{CO}_{2}$. After two days, MTT was added with a final concentration of $0.5 \mathrm{mg} / \mathrm{mL}$ to each well, and the plates were incubated for an extra $4 \mathrm{~h}$ at $37{ }^{\circ} \mathrm{C}$ in the presence of $5 \% \mathrm{CO}_{2}$. Color intensity was measured using an ELISA reader. The correlation between survivor fracture and drug intake was drawn to obtain a survival curve for the MCF-7 cancer cell line after the specific concentration of the synthesized compounds. All experiments were performed in triplicates. 


\subsubsection{Cell Cycle Analysis}

To study the effect of the synthesized compounds on the cell cycle, approximately $2 \times 10^{5}$ /well MCF-7 cells were treated with compound 6 at its IC 50 value for two days. After exposure to this process, cells were washed twice with ice-cold phosphate saline (PBS) and then cells were collected by centrifugation, followed by fixing of the cells in ice-cold $70 \%$ ethanol at $4{ }^{\circ} \mathrm{C}$ for $30 \mathrm{~min}$. Cells were washed using $1 \times \mathrm{PBS}$ solution at $37^{\circ} \mathrm{C}$ for $30 \mathrm{~min}$. After that, cells were collected using centrifugation at light speed (2000 rpm) for $5 \mathrm{~min}$, and then cells were stained with a solution of propidium iodide at a final concentration of $1 \mu \mathrm{g} / \mathrm{mL}$. The samples were mixed gently and left at room temperature in the dark for $20 \mathrm{~min}$. DNA content was investigated via a BD FACSCanto flow cytometer (BD Biosciences Systems, San Jose, CA, USA). The results were analyzed using FACSDiva software (BD Biosciences Systems).

\subsubsection{Apoptosis Determination by Annexin- $V$ Assay}

The MCF-7 cells $\left(2 \times 10^{5}\right.$ /well) were incubated with compound 6 at its $\mathrm{IC}_{50}$ concentration value for $48 \mathrm{~h}$. Next, cells were collected and washed twice with PBS at low speed (2000 rpm for $10 \mathrm{~min}$ at $4{ }^{\circ} \mathrm{C}$ ). All cells were dissolved in $100 \mu \mathrm{L}$ of a binding solution, and then $5 \mu \mathrm{L}$ of Annexin V-FITC was added. Then, cells were incubated for $10 \mathrm{~min}$ at room temperature, additional $400 \mu \mathrm{L}$ of binding solution was added. Next, cells were stained with PI stain and examined with a FACSCalibur flow cytometer (Becton and Dickinson, Heidelberg, Germany). The obtained results were analyzed using Cell-Quest software (Becton and Dickinson, Heidelberg, Germany).

\subsubsection{Statistical Analysis}

Statistical comparisons were measured by a one-way ANOVA with Duncan's test using IBM SPSS version 26 . A probability level of 0.05 or lower was considered statistically significant; ${ }^{* *} p<0.01$.

\section{Conclusions}

The medicinal properties of coumarin have been discovered due to its presence in various medicinal plants. Therefore, coumarin has different biological activities and has a positive effect on human health. The present study focused on the synthesis of substituted azacoumarin-3-carboxylic acids as 1- $\mathrm{N}$-(acetyl)-azacoumarin-3-carboxylic acid (4), 1-N-(2formyl-1-phenyl) vinyl-azacoumarin-3-carboxylic acids (5), 1- $N$-[2-(hydroxy) caybonyl-1(phenyl) vinyl]-azacoumarin-3-carboxylic acid (6) and 1-N-(4-cyano-5-methoxy-5-oxo-1phenylpenta-1,3-diene-1-y)-azacoumarin-3-cayboxylic acid (9). The chemical structures of these compounds were discussed based on the elemental analyses, infrared, and proton NMR spectroscopy. All the synthesized quinolinone derivatives were investigated for their cytotoxic activity against the MCF-7 cell line. Compound $\mathbf{6}$ was considered the most capable anti-cancer drug among the tested compounds. The mechanism of action was assessed using flow cytometric assay. The data revealed that the compound $\mathbf{6}$ was able to arrest the cell cycle in the G2/M phase and pre-G1 apoptosis.

Supplementary Materials: The following are available online at https:/ /www.mdpi.com/article/10 .3390/ cryst11050565/s1, Figure S1: FT-IR spectrum of compound (3), Figure S2: ${ }^{1} \mathrm{H}-\mathrm{NMR}$ spectrum of compound (3), Figure S3: ${ }^{13} \mathrm{C}-\mathrm{NMR}$ spectrum of compound (3), ${ }^{1} \mathrm{H}-\mathrm{NMR}$ spectrum of compound (4), Figure S5: ${ }^{13} \mathrm{C}-\mathrm{NMR}$ spectrum of compound (4), Figure S6: ${ }^{1} \mathrm{H}-\mathrm{NMR}$ spectrum of compound (5), Figure S7: ${ }^{13} \mathrm{C}-\mathrm{NMR}$ spectrum of compound (5), Figure S8: ${ }^{1} \mathrm{H}-\mathrm{NMR}$ spectrum of compound (6), Figure S9: ${ }^{13} \mathrm{C}-\mathrm{NMR}$ spectrum of compound (6), Figure S10: ${ }^{1} \mathrm{H}-\mathrm{NMR}$ spectrum of compound (9), Figure S11: ${ }^{13} \mathrm{C}-\mathrm{NMR}$ spectrum of compound (9).

Author Contributions: Conceptualization, M.S.R. and I.M.E.-D.; methodology, I.M.E.-D., M.S.R. and A.G.; software, I.M.E.-D. and M.S.R.; validation, W.F.A., M.A. and A.S.A.; formal analysis, A.G., W.F.A., M.A., A.S.A. and M.S.R.; investigation, A.G., M.A., A.S.A. and M.S.R.; data curation, A.G., I.M.E.-D. and M.S.R.; writing-original draft preparation, I.M.E.-D. and M.S.R.; writing- 
review and editing, A.G. and W.F.A.; supervision, W.F.A. and M.S.R.; project administration, A.G.; funding acquisition, A.G. and W.F.A. All authors have read and agreed to the published version of the manuscript.

Funding: The authors appreciate the Taif University Researchers Supporting Project (number TURSP2020/39), Taif University, Taif, Saudi Arabia.

Institutional Review Board Statement: Not applicable.

Informed Consent Statement: Not applicable.

Data Availability Statement: The data used to support the results of the present research are included in the article.

Acknowledgments: The authors are appreciative of the support of Taif University Researchers Supporting Project (number TURSP-2020/39), Taif University, Taif, Saudi Arabia.

Conflicts of Interest: The authors declare no conflict of interest.

\section{References}

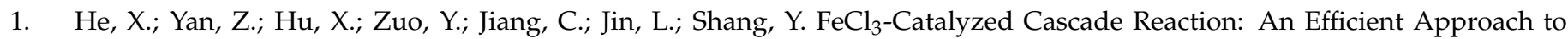
Functionalized Coumarin Derivatives. Synth. Commun. 2014, 44, 1507-1514. [CrossRef]

2. Barot, K.P.; Jain, S.V.; Kremer, L.; Singh, S.; Ghate, M.D. Recent advances and therapeutic journey of coumarins: Current status and perspectives. Med. Chem. Res. 2015, 24, 2771-2798. [CrossRef]

3. Liu, H.; Ren, Z.-L.; Wang, W.; Gong, J.-X.; Chu, M.-J.; Ma, Q.-W.; Wang, J.-C.; Lv, X.-H. Novel coumarin- pyrazole carboxamide derivatives as potential topoisomerase II inhibitors: Design, synthesis and antibacterial activity. Eur. J. Med. Chem. 2018, 157, 81-87. [CrossRef]

4. Wei, Y.; Li, S.Q.; Hao, S.H. New angular oxazole-fused coumarin derivatives: Synthesis and biological activities. Nat. Prod. Res. 2018, 32, 1824-1831. [CrossRef] [PubMed]

5. Pérez-Cruz, K.; Moncada-Basualto, M.; Morales-Valenzuela, J.; Barriga-González, G.; Navarrete-Encina, P.; Núñez-Vergara, L.; Squella, J.; Olea-Azar, C.; Barriga, G. Synthesis and antioxidant study of new polyphenolic hybrid-coumarins. Arab. J. Chem. 2018, 11, 525-537. [CrossRef]

6. Bagheri, S.M.; Khoobi, M.; Nadri, H.; Moradi, A.; Emami, S.; Jalili-Baleh, L.; Jafarpour, F.; Moghadam, F.H.; Foroumadi, A.; Shafiee, A. Synthesis and Anticholinergic Activity of 4-hydroxycoumarin Derivatives Containing Substituted Benzyl-1,2,3-triazole Moiety. Chem. Boil. Drug Des. 2015, 86, 1215-1220. [CrossRef]

7. Chen, L.Z.; Sun, W.W.; Bo, L.; Wang, J.Q.; Xiu, C.; Tang, W.J.; Shi, J.B.; Zhou, H.P.; Liu, X.H. New arylpyrazoline-coumarins: Synthesis and anti-inflammatory activity. Eur. J. Med. Chem. 2017, 138, 170-181. [CrossRef] [PubMed]

8. Olmedo, D.; Sancho, R.; Bedoya, L.M.; López-Pérez, J.L.; Del Olmo, E.; Muñoz, E.; Alcami, J.; Gupta, M.P.; Feliciano, A.S. 3-Phenylcoumarins as Inhibitors of HIV-1 Replication. Molecules 2012, 17, 9245-9257. [CrossRef]

9. Emami, S.; Dadashpour, S. Current developments of coumarin-based anti-cancer agents in medicinal chemistry. Eur. J. Med. Chem. 2015, 102, 611-630. [CrossRef]

10. Keri, R.S.; Sasidhar, B.S.; Nagaraja, B.M.; Santos, M.A. Recent progress in the drug development of coumarin derivatives as potent antituberculosis agents. Eur. J. Med. Chem. 2015, 100, 257-269. [CrossRef]

11. Akoudad, S.; Darweesh, S.K.; Leening, M.J.; Koudstaal, P.J.; Hofman, A.; Van Der Lugt, A.; Stricker, B.H.; Ikram, M.A.; Vernooij, M.W. Use of Coumarin Anticoagulants and Cerebral Microbleeds in the General Population. Stroke 2014, 45, 3436-3439. [CrossRef] [PubMed]

12. Hassan, M.Z.; Osman, H.; Ali, M.A.; Ahsan, M.J.; Ahsan, M.J. Therapeutic potential of coumarins as antiviral agents. Eur. J. Med. Chem. 2016, 123, 236-255. [CrossRef] [PubMed]

13. Wijayabandara, M.D.J.; Choudhary, M.I.; Adhikari, A. Characterization of an anti-hyperglycemic coumarin from the fruits of Averrhoa. In Proceedings of the Annual Scientific Sessions of Faculty of Medical Sciences, Nugegoda, Sri Lanka, 2 April 2015.

14. Keshavarzipour, F.; Tavakol, H. The synthesis of coumarin derivatives using choline chloride/zinc chloride as a deep eutectic solvent. J. Iran. Chem. Soc. 2016, 13, 149-153. [CrossRef]

15. Suljić, S.; Pietruszka, J. Synthesis of 3-Arylated 3,4-Dihydrocoumarins: Combining Continuous Flow Hydrogenation with Laccase-Catalysed Oxidation. Adv. Synth. Catal. 2014, 356, 1007-1020. [CrossRef]

16. Pinto, L.D.S.; De Souza, M.V.N. Sonochemistry as a General Procedure for the Synthesis of Coumarins, Including Multigram Synthesis. Synthesis 2017, 49, 2677-2682.

17. Yadav, D.K.; Rai, R.; Kumar, N.; Singh, S.; Misra, S.; Sharma, P.; Shaw, P.; Perez-Sanchez, H.; Mancera, R.L.; Choi, E.H.; et al. New arylated benzo[ $h]$ quinolines induce anti-cancer activity by oxidative stress-mediated DNA damage. Sci. Rep. 2016, 6, 38128. [CrossRef]

18. Kim, Y.-H.; Shin, K.-J.; Lee, T.G.; Kim, E.; Lee, M.-S.; Ryu, S.H.; Suh, P.-G. G2 arrest and apoptosis by 2-amino-N-quinoline-8-ylbenzenesulfonamide (QBS), a novel cytotoxic compound. Biochem. Pharmacol. 2005, 69, 1333-1341. [CrossRef] 
19. Zhao, Y.-L.; Chen, Y.-L.; Chang, F.-S.; Tzeng, C.-C. Synthesis and cytotoxic evaluation of certain 4-anilino-2-phenylquinoline derivatives. Eur. J. Med. Chem. 2005, 40, 792-797. [CrossRef]

20. Pottier, C.; Fresnais, M.; Gilon, M.; Jerusalem, G.; Longuespee, R.; Sounni, N.E. Tyrosine Kinase Inhibitors in Cancer: Breakthrough and Challenges of Targeted Therapy. Cancers 2020, 12, 731. [CrossRef]

21. Alqasoumi, S.I.; Al-Taweel, A.M.; Alafeefy, A.M.; Hamed, M.M.; Noaman, E.; Ghorab, M.M. Synthesis and biological evaluation of 2-amino-7, 7-dimethyl 4-substituted-5-oxo-1-(3, 4, 5-trimethoxy)-1, 4, 5, 6, 7, 8-hexahydro-quinoline-3-carbonitrile derivatives as potential cytotoxic agents. Bioorg. Med. Chem. Lett. 2009, 19, 6939-6942. [CrossRef]

22. Mulvihill, M.J.; Ji, Q.-S.; Coate, H.R.; Cooke, A.; Dong, H.; Feng, L.; Foreman, K.; Honda, A.; Mak, G.; Mulvihill, K.M. Novel 2-phenylquinolin-7-yl-derived imidazo [1,5-a] pyrazines as potent insulin-like growth factor-I receptor (IGF-IR) inhibitors. Bioorg. Med. Chem. 2008, 16, 1359-1375. [CrossRef]

23. Nishii, H.; Chiba, T.; Morikami, K.; Fukami, T.A.; Sakamoto, H.; Ko, K.; Koyano, H. Discovery of 6-benzyloxyquinolines as c-Met selective kinase inhibitors. Bioorg. Med. Chem. Lett. 2010, 20, 1405-1409. [CrossRef] [PubMed]

24. Pannala, M.; Kher, S.; Wilson, N.; Gaudette, J.; Sircar, I.; Zhang, S.-H.; Bakhirev, A.; Yang, G.; Yuen, P.; Gorcsan, F. Synthesis and structure-activity relationship of 4-(2-aryl-cyclopropylamino)-quinoline-3-carbonitriles as EGFR tyrosine kinase inhibitors. Bioorg. Med. Chem. Lett. 2007, 17, 5978-5982. [CrossRef]

25. Kubo, K.; Shimizu, T.; Ohyama, S.-I.; Murooka, H.; Iwai, A.; Nakamura, K.; Hasegawa, K.; Kobayashi, Y.; Takahashi, N.; Takahashi, K. Novel potent orally active selective VEGFR-2 tyrosine kinase inhibitors: Synthesis, structure- activity relationships, and antitumor activities of n-phenyl-n '-\{4-(4-quinolyloxy) phenyl\} ureas. J. Med. Chem. 2005, 48, 1359-1366. [CrossRef]

26. Matsui, J.; Yamamoto, Y.; Funahashi, Y.; Tsuruoka, A.; Watanabe, T.; Wakabayashi, T.; Uenaka, T.; Asada, M. E7080, a novel inhibitor that targets multiple kinases, has potent antitumor activities against stem cell factor producing human small cell lung cancer H146, based on angiogenesis inhibition. Int. J. Cancer 2008, 122, 664-671. [CrossRef] [PubMed]

27. Campas, C.; Bolos, J.; Castaner, R. TIVOZANIB VEGFR Tyrosine Kinase Inhibitor Angiogenesis Inhibitor Oncolytic. Drugs Future 2009, 34, 793-796. [CrossRef]

28. Kemnitzer, W.; Kuemmerle, J.; Jiang, S.; Zhang, H.-Z.; Sirisoma, N.; Kasibhatla, S.; Crogan-Grundy, C.; Tseng, B.; Drewe, J.; Cai, S.X. Discovery of 1-benzoyl-3-cyanopyrrolo[1,2-a]quinolines as a new series of apoptosis inducers using a cell- and caspase-based high-throughput screening assay. Part 1: Structure-activity relationships of the 1- and 3-positions. Bioorg. Med. Chem. Lett. 2008, 18, 6259-6264. [CrossRef] [PubMed]

29. Zeydi, M.M.; Kalantarian, S.J.; Kazeminejad, Z. Overview on developed synthesis procedures of coumarin heterocycles. J. Iran. Chem. Soc. 2020, 17, 3031-3094. [CrossRef]

30. Annunziata, F.; Pinna, C.; Dallavalle, S.; Tamborini, L.; Pinto, A. An overview of coumarin as a versatile and readily accessible scaffold with broad-ranging biological activities. Int. J. Mol. Sci. 2020, 21, 4618. [CrossRef]

31. Song, X.F.; Fan, J.; Liu, L.; Liu, X.F.; Gao, F. Coumarin derivatives with anticancer activities: An update. Arch. Pharm. 2020, 353, e2000025. [CrossRef]

32. Akkol, E.K.; Genç, Y.; Karpuz, B.; Sobarzo-Sánchez, E.; Capasso, R. Coumarins and coumarin-related compounds in pharmacotherapy of cancer. Cancers 2020, 12, 1959. [CrossRef] [PubMed]

33. Al-Warhi, T.; Sabt, A.; Elkaeed, E.B.; Eldehna, W.M. Recent advancements of coumarin-based anticancer agents: An up-to-date review. Bioorg. Chem. 2020, 103, 104163. [CrossRef] [PubMed]

34. Goud, N.S.; Kumar, P.; Bharath, R.W. Recent developments of target based coumarin derivatives as potential anticancer agents. Mini-Rev. Med. Chem. 2020, 20, 1754-17668. [CrossRef]

35. Endo, S.; Oguri, H.; Segawa, J.; Kawai, M.; Hu, D.; Xia, S.; Okada, T.; Irie, K.; Fujii, S.; Gouda, H.; et al. Development of novel AKR1C3 inhibitors as new potential treatment for castration-resistant prostate cancer. Med. Chem. 2020, 63, 10396-10411. [CrossRef]

36. Wang, C.; Xi, D.; Wang, H.; Niu, Y.; Liang, L.; Xu, F.; Peng, Y.; Xu, P. Hybrids of MEK inhibitor and NO donor as multitarget antitumor drugs. Eur. J. Med. Chem. 2020, 196, 112271. [CrossRef] [PubMed]

37. Torres, K.; Horwitz, S.B. Mechanisms of taxol-induced cell death are concentration dependent. Cancer Res. 1998, 58, 3620-3626. [PubMed]

38. Murray, A.W. Recycling the cell cycle: Cyclins revisited. Cell 2004, 116, 221-234. [CrossRef]

39. Kwan, Y.P.; Saito, T.; Ibrahim, D.; Al-Hassan, F.M.; Ein Oon, C.; Chen, Y.; Jothy, S.L.; Kanwar, J.R.; Sasidharan, S. Evaluation of the cytotoxicity, cell-cycle arrest, and apoptotic induction by Euphorbia hirta in MCF-7 breast cancer cells. Pharm. Biol. 2016, 54, $1223-1236$ 